\title{
ŚW. BARNABA W HISTORII I LEGENDZIE
}

Postać św. Barnaby nie cieszy się zbytnim zainteresowaniem ze strony uczonych ${ }^{1}$. Wprawdzie encyklopedie, tak zagraniczne, jak i polskie, poświęcają mu nieco miejsca, ale ograniczają się zazwyczaj do danych biblijnych, a nie uwzględniają legendy św. Barnaby, jej historycznych uwarunkowań i konsekwencji. Po pracach Braunsbergera i Lipsiusa niewiele nowego napisano na jego temat, jak to widać z bibliografii, załączonej na końcu niniejszego artykułu (aneks II). Również w planie wielotomowego wydania Dziejów apostolskich apokryficznych, podjętego przez ekipy uczonych francuskich i Szwajcarii romańskiej, nie znajdujemy legendy św. Barnaby.

Należy również dodać, że niewielu pisarzy w okresie Ojców interesowało się postacią towarzysza św. Pawła; znajdujemy u nich tylko zwięzłe wzmianki. Podróże i męczeństwo Barnaby oraz Panegiryk pióra Aleksandra mnicha i $\mathrm{Hi}$ storia Datiana, opowiadające o Barnabie, nie należą do utworów szczególnie ciekawych. Poniższe opracowanie powstało w ramach przygotowywania do druku przekładu polskiego apokryficznych Dziejów apostolskich.

\section{BARNABA W PIŚMIE SW.}

Źródłem do poznania postaci św. Barnaby są przede wszystkim Dzieje apostolskie, uzupełnione w kilku miejscach wzmiankami w listach św. Pawła.

Barnaba pochodził z Cypru. Mial na imię Józef i należał do pokolenia Lewiego $(\mathrm{Dz} 4,26)$. O jego młodości nic nie wiemy. Domyślamy się jednak, że osiedlił się w Jerozolimie, gdyż tam miał jakąś posiadłość (Dz 4,37). Te wiadomości „uzupełnia” mnich Aleksander, opierając się — jak twierdzi — na Klemensie Aleksandryjskim, na dawnych pismach oraz na przekazach starszych. Jego nauczycielem miał być Gamaliel (a więc ten sam nauczyciel, który był mistrzem św. Pawła - por. Dz 23,3; to wyjaśniałoby związek obydwu apostołów). Nawrócił się po uzdrowieniu paralityka przy Sadzawce Owczej (J 5,2 -

${ }^{1}$ Zob. bibliografię na końcu artykułu. Wszystkie skróty wydawnictw źródłowych podaję według systemu przyjętego w Encyklopedii katolickiej KUL. 
15) i przyprowadził do Chrystusa swoją ciotkę Marię, matkę Jana Marka. Barnaba zaprowadził Chrystusa do Galilei i tam został przez Niego wyznaczony pierwszym spośród 70 uczniów² ${ }^{2}$ Tam też otrzymał, za Bożym zrządzeniem, nowe imię: Barnaba. Kodeksy Nowego Testamentu mylą Barnabę i Barsabasa, współzawodnika do tyłu apostoła Macieja ${ }^{3}$. Ps. Klemens (Recognitiones 1,60 ) idzie dalej, identyfikując go z samym Maciejem.

Barnaba sprzedał swe dobra i pieniądze złożył u stóp apostołów (Dz 4,37). Wtedy też zmieniono mu imię na Barnaba, które Łukasz tlumaczy niedokładnie jako „syn pocieszenia”, podczas gdy istotnie „bar nabuah” znaczy „syn proroka"4. Jak dowiadujemy się z Listu do Kolosan $(4,10)$ św. Marek był jego o̊ve$\psi$ ıó , co może znaczyć zarówno bratanek (siostrzeniec), jak i kuzyn ${ }^{5}$. Te dane czynią możliwymi wiadomości Aleksandra, że Barnaba był jednym z uczniów Jezusa.

Barnaba musiał mieć wysoką pozycję w Jerozolimie, skoro po nawróceniu Pawła i jego ucieczce z Damaszku stał się jego gwarantem i nie tylko zaprowadził go do starszych w Jerozolimie, ponadto potrafił przełamać otaczającą Pawła nieufność $(\mathrm{Dz} 9,27)$. I znowu te wiadomości mogłyby potwierdzać dane Aleksandra o uprzedniej znajomości Barnaby i Pawła.

Gdy chrześcijaństwo wzrastało w Antiochii, apostołowie wysłali tam Barnabę, który uradował się, widząc sytuację w Antiochii i zachęcał wiernych, aby całym sercem trwali przy Panu, bo sam był człowiekiem dobrym i pełnym Ducha św. (Dz 11,22). Wysłanie Barnaby, cypryjczyka, do Antiochii nie było bynajmniej dziełem przypadku, jako że chrześcijanie cypryjscy po śmierci Szczepana udali się do Antiochii, aby tam głosić słowo Boże (Dz 11, 19n.). Działalność Barnaby przynosiła owoce i wielu przyłączyło się do Pana. Wtedy po raz drugi interweniuje Barnaba w sprawie Pawła: odnajduje go w Tarsie i około 43 r. przyprowadza do Antiochii (Dz 11, 25 n.). Tam pracują wspólnie, uważani za proroków i nauczycieli (Dz 13,1).

Gdy w Jerozolimie wybuchł głód, w bogatej Antiochii zebrano składkę i wysłano z nią do Jerozolimy Barnabę i Pawła (Dz 11,30). Po cudownym uwoInieniu Piotra, powracają oni do Antiochii, zabierając z sobą Jana, zwanego Markiem (Dz 12,35). Praca Barnaby i Pawła była tak owocna, że postanowiono ich wysłać na pierwszą wielką misję do pogan: Pewnego razu, gdy odprawiali publiczne nabożeństwo i prosili Ducha św., powiedział im tak: „Zostawcie mi już Barnabę i Szawła, by mogli poświęcić się sprawie, do której ich powoła-

2 Podobnie Klemens Aleksandryjski w Hypotyposes, cytowany przez Euzebiusza z Cezarei (HK 1, 12, 1-3, Stromata 2, 20, 16). Por. spisy 70 uczniów, które podaje T. S ch e r m a n n: Prophetarum vitae fabulosae, indices apostolorum..., Lipsiae 1907, s. 127, 4; 189, 15.

${ }^{3}$ Por. aparat krytyczny wydań tekstu greckiego do Dz $1,23$.

${ }^{4}$ E. Pow e r, Barnabas, DB 2, 1461.

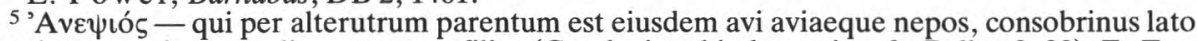
sensu, i. e. patrui, avunculi, meterterae filius (Geschwisterkind, cousin, cfr. Pollux 3, 28): F. Zorel1, Lexicon Graecum Novi Testamenti, Parisiis 1961, s. 113. 
łem". Wyprawili ich tedy w drogę po uprzednim poście, modlitwie i włożeniu na nich rąk $(\mathrm{Dz} 13,2 \mathrm{n})^{6}$.

Ta pierwsza podróż miała miejsce w latach 45 - 49. Jest rzeczą charakterystyczną, że wyruszyli oni najpierw na Cypr, do ojczyzny Barnaby, co dobitnie podkreśla jego rolę. Swą misję rozpoczęli od Salaminy, portu najbliższego od strony Antiochii, następnie przeszli przez całą wyspę, nauczając Żydów, aż do Pafos, gdzie rezydował prokonsul rzymski, który zainteresował się ich nauką; spotkaniu z nimi starał się przeszkodzić prorok $(\delta \mu \alpha ́ \gamma \gamma \varsigma)$ Barjesus, po grecku

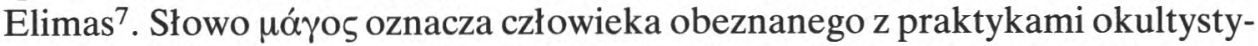
cznymi, bardzo popularnymi w tej epoce, w której filozofia, nauka i okultyzm splatały się ze sobą w jedno. Był on prawdopodobnie magiem jak Szymon Mag (Dz 8,5-24) czy cypryjczyk Atamos na dworze prokonsula Feliksa ${ }^{8}$; ewentualną możliwość identyfikacji tych dwóch postaci przyjmuje cytowany A. Romeo. Konflikt z Bar Jesu zakończony jego oślepieniem (niektórzy pisarze epoki patrystycznej uznają je tylko za chwilowe) ${ }^{9}$ kończy wyprawę cypryjską; Barnaba i Paweł opuszczają Cypr i udają się do Perge w Pamfilii, gdzie opuścił ich Jan Marek, który powrócił do Jerozolimy (Dz 13,4 - 13).

Drugim etapem tej podróży misyjnej jest wędrówka przez Azję Mniejszą: Pamfilię, Pizydię i Likaonię, nauczając kolejno w Antiochii Pizydyjskiej (Dz 13,11 - 51), Ikonium (Dz 14,1 - 5), Derbe (Dz 14,6.21). W Listrze (Dz 14,8 -20) pełni zachwytu poganie biorą ich za bogów: Barnabę za Zeusa, Pawła za Hermesa. Spotkawszy się z oporem Żydów zaczęli glosić naukę poganom, co spowodowało wybuch prześladowań ze strony Żydów. Po skończonej wyprawie tą samą drogą powracają do Perge i Attalii, a stamtąd statkiem do Antiochii. W czasie tej podróży widzimy wyraźnie przestawienie akcentów: Barnaba, który wprowadzil Pawła w życie gminy, nadaje ton jeszcze na początku wyprawy, teraz ustępuje pierwsze miejsce Pawłowi.

Działalność Pawła i Barnaby wśród pogan wywołała w Antiochii entuzjazm, ale i niepokój pośród judeochrześcijan, którzy domagali się obrzezania pogan przyjmujących chrześcijaństwo. W obliczu tych sporów Paweł i Barnaba zostają wysłani do Jerozolimy, dokąd udali się przez Fenicję i Samarię, gdzie wiadomość o nawróceniach wśród pogan wywołuje radość ( $\mathrm{Dz} 15,1-4)$. W Jerozolimie przyjęto ich serdecznie $(\mathrm{Gal} 2,1.9)$.

Na tzw. soborze jerozolimskim Barnaba i Paweł złożyli relację ze swej wyprawy. Apostołowie udzielili poparcia ich działalności, co widać z listu soboru, skierowanego do antiocheńczyków, a wysłanego przez Judę i Sylasa, którym towarzyszyli Paweł i Barnaba; obydwaj pozostali w Antiochii, aby głosić Sło-

${ }^{6}$ Cytaty z Nowego Testamentu według przekładu bpa K. Romaniuka (Poznań 1976).

${ }^{7}$ E. Dąbrowski, Pawet $z$ Tarsu, Warszawa 1953, s. $116-120$. O Barjesu por. artykuły w encyklopediach: A. Rom e o, EK 2 s. 552 n.; E. Ja cqui er, DB 1 s. 461.

${ }^{8}$ Iosephus Fla viu s, Antiquitates $20,7,2$.

${ }^{9} \mathrm{~Np}$. O rig en es, In Exodum Commentarii fragmenta, PG 12 s. 1276. 
wo Boże (Dz 15,35). Jak się dowiadujemy ze wzmianki u św. Pawła, pracowali zarobkowo (1 Kor 9,6).

Sprawa jednak przyjmowania pogan do Kościoła nie została bynajmniej zakończona. Gdy do Antiochii przybył Piotr, zajął najpierw stanowisko zgodne z postanowieniami jerozolimskimi, następnie jednak zaczął się odsuwać od pogan, którzy przyjęli chrześcijaństwo; za nim, po pewnym wahaniu, poszedł i Barnaba, na co ostro zareagował Paweł (Gal 2,11 - 14). Być może tu leży jedno ze źródeł konfliktu Pawła i Barnaby na początku drugiej podróży apostolskiej.

W r. 50 Paweł postanowił wyruszyć w nową podróż apostolską, aby odwiedzić braci, którym uprzednio głosił Ewangelię. Chciał wziąć z sobą wypróbowanego towarzysza podróży, jakim był Barnaba. Ten jednak nalegał, aby poszedł z nimi również Jan Marek. Ale Paweł nie życzył sobie, by towarzyszył im ten, który ich niegdyś opuścił w Pamfilii. Doszło przy tym do ostrego spięcia i rozdzielili się: Paweł z Sylasem wyruszyli do Azji Mniejszej. Barnaba natomiast z Markiem udał się na Cypr (Dz 15,36-39). Spór z Markiem był, jak się wydaje, chwilowy. Ciepłe wzmianki o obydwu towarzyszach pierwszej podróży w Listach św. Pawła (Kol 4,10; 2 Tm 4,11) mogłyby świadczyć, że, jak czytamy w Historia Datiana, spierali się corpore non animo ${ }^{10}$.

W tym miejscu kończą się dane biblijne, a zarazem dane historyczne o Barnabie. Na ich podstawie możemy powiedzieć, że był on wybitnym i gorliwym apostołem i duszpasterzem, współzałożycielem Kościoła antiocheńskiego i cypryjskiego. Jego wielką zasługą było wprowadzenie św. Pawła do gminy jerozolimskiej, a potem antiocheńskiej. Sw. Hieronim (†419) w biogramie Barnaby w De viris illustribus pisze, że odłączył się on wprawdzie od Pawła, ale nie od obowiązku głoszenia Ewangeliii ${ }^{11}$. W tym miejscu rozpoczyna się legenda opisująca jego działalność na Cyprze.

Pozostaje jeszcze powiedzieć kilka słów o pismach przypisywanych Barnabie. Oto one:

1. List Barnaby. Dzieło powstałe w połowie II w. Według niektórych rękopisów, jego autorem miałby być Barnaba, towarzysz św. Pawła. Ten pogląd, uznawany przez niektórych pisarzy starożytnych, jest dziś powszechnie odrzucony. Jest natomiast rzeczą możliwą, że jest to istotnie dzieło jakiegoś bliżej nieznanego Barnaby, które to imię należało do imion popularnych w świecie śródziemnomorskim ${ }^{12}$.

2. Sw. Barnabie przypisywano autorstwo Listu do Hebrajczyków. Opinia ta,

${ }^{10}$ S. 16, ed. A. i E. Col o m b o, De vita civitatis Mediolani, de adventu Barnabae apostoli [...], Bologna 1952, s. 14-21.

${ }_{11} \mathrm{O}$ mężach sławnych 6, PSP 6 s. 32.

12 Por. Epître de Barnabé, ed. P. Prige nt, R. A. Kraft, SCh 172 s. 25 n., 27 n. Euzebiusz nie uważa tego listu za autentyczny, ale za antilegomenon (HK 3, 25, 4), Orygenes natomiast (Contra Celsum 1,63) nazywa go katolickim. 
której pierwszym świadkiem jest Tertulian († ok. 220 r.), miała swoich zwolenników w świecie starożytnym; dziś jest ona powszechnie odrzucona ${ }^{13}$.

3. Istnieje apokryficzna Ewangelia Barnaby, w całości zachowana w przekładzie starowłoskim z ok. 1500 r., wykazująca tendencje mahometańskie, ale zawierająca równocześnie elementy judeochrześcijańskie. Nie można stwierdzić, czy ma ona jakiś związek z Ewangelia Barnaby cytowaną w Dekrecie Gelazjańskim $(2,3)^{14}$.

4. W Kodeksie Baroccianus 39 znajdujemy logion przypisywany Barnabie: Barnaba apostoł powiedział: „W złych zawodach bardziej nieszczęśliwy jest ten, kto zwycięża, ponieważ odchodzi napełniony grzechem". Na temat autentyczności tego logionu nie jesteśmy w stanie nic powiedzieć: może być on równie autentyczny, jak i nieautentyczny ${ }^{15}$.

\section{LEGENDA CYPRYJSKA}

Legenda cypryjska św. Barnaby jest tak ściśle związana z dziejami Kościoła cypryjskiego, że, aby ją zrozumieć, trzeba najpierw omówić dzieje Kościoła na Cyprze w pierwszych pięciu wiekach ${ }^{16}$.

Po śmierci Szczepana wielu chrześcijan uciekło z Jerozolimy, niektórzy spośród nich, z pochodzenia cypryjczycy, powrócili na wyspę $(\mathrm{Dz} 11,19)$. Stąd też misja Barnaby, Pawła i Jana Marka na Cyprze w roku 45 była ułatwiona: przeszli oni przez cały Cypr, od wschodu wyspy (Salamina) na zachód (Pafos), głosząc Żydom słowó Boże. Uwieńczeniem misji było spotkanie się z prokonsulem Sergiuszem Pawłem, którego legenda chrześcijańska zrobiła pierwszym biskupem Narbonne, i zwycięskie starcie z magiem Barjesu (Dz 13,4 - 13). Druga podróż misyjna miała miejsce w 51 r.: odbyli ją już tylko Barnaba i Jan Marek (Dz 15,39); Dzieje apostolskie informują nas o jej rozpoczęciu, ale nie podają żadnych bliższych szczegółów o niej.

Z okresu od połowy I do IV w. brak źródeł historycznych do historii chrześcijaństwa na Cyprze. Natomiast legenda obdarzyła obficie wyspę świętymi biskupami ${ }^{17}$. Biskupami na wyspie mieli być, by podać kilka przykładów: Aryston umęczony w Salaminie, Heraklides - pierwszy biskup Tamasos wyświęcony przez św. Pawła i umęczony w Salaminie, Arystobul — brat św. Barnaby

13 Tertullianus, De pudicitia 20,2, CChrL 2s. 1324; Gregorius Illiberit anus, Tractatus Origenis, PLS 2 s. 1324; K a s jod or, In Romanos (introductio), PL 68, 416 (por. Clavis Patrum Latinorum 902); Phil as tri u s B rixi e ns is, Haeresis 89, PL 12, 1200.

${ }^{14}$ Por. ANT 1, 172.

15 PG 2, 781; A. Res ch, Agrapha, Leipzig 1906, s. 282 (nr 77).

16 O Kościele na Cyprze por.: H. Le cle r q, DACL 3/1 s. 1568 - 1584; R. J a n in, DHGE 12 s. $791-820$; E. Kirsten, RAC 3 s. $481-499$.

17 Por. artykuły H. Delehaye i F. Nau w bibliografii. Słuszna uwaga Papenbroecha (AASS 430): Non dubitem, quin Timon, Ariston, Heraclides, Rhodon, Aristoclianus vera sint nomina sanctorum, quibus suus olim cultus fuerit. 
apostoła, jeden z 70, który następnie został biskupem w Brytanii(!). Mnason - uczeń św. Pawła (Dz 21,16), Epafras - wspomniany również przez św. Pawła (Kol 1,7: 4,12: Fil 23), Tychik — biskup Neapolis (Dz 20,4: Ef 6,21: 2 Tm 4,7: Tt 3,12), Filargiusz - biskup Soli, Łazarz — brat Marii i Marty, biskup Kition, Tytus - urodzony w Pafos, adresat Listu św. Pawła, umęczony na Cyprze, wspomniany już biskup Narbonne - Sergiusz Paulus, Nikanor — jeden z siedmiu diakonów itd. Szczególną rolę odgrywa w legendzie apostoł Barnaba, Auksybiusz ${ }^{18}$ i Heraklides ${ }^{19}$, których późne życiorysy się zachowały.

$\mathrm{Na}$ Cyprze znajdowały się wielkie kolonie Żydów, którzy osiedlili się tu po odstąpieniu Herodowi kopalni miedzi przez cesarza Augusta ${ }^{20}$. Oni też byli pierwszymi adresatami nauki apostołów, ale i oni stawiali potężny opór rozwijającemu się chrześcijaństwu; reminiscencje tego spotykamy w Podróżach Barnaby. W 116 r. wybuchło przeciw Rzymianom powstanie Żydów cypryjskich, którzy dokonali masakry tamtejszej ludności. Wedle zapewne mocno zawyżonych danych, mieli wtedy wymordować 250000 cypryjczyków ${ }^{21}$. Po stłumieniu powstania zakazano Żydom wstępu na Cypr.

$\mathrm{Z}$ początku IV w. pochodzą znowu wiadomości historyczne, które pokazują, jak Cypr zaczyna odgrywać rolę w dziejach Kościoła. W czasie wielkiego prześladowania chrześcijan w początku IV w. wysłano do kopalń cypryjskich część chrześcijan pracujących w kopalniach palestyńskich ${ }^{22}$. Na soborze nicejskim w 325 r. byli obecni biskupi z Cypru: Cyryl z Pafos oraz Gelazy z Salaminy ${ }^{23}$; miał być również obecny na soborze wielki cudotwórca, biskup Spiridion z Trimithonte ${ }^{24}$. Wedle legendy, w $327 \mathrm{r}$. Cypr odwiedziła cesarzowa Helena i wystawiła kilka kościołów ${ }^{25}$. Na soborze konstantynopolitańskim pierwszym było obecnych czterech biskupów cypryjskich; brał w nim udział wielki teolog, biskup Salaminy, Epifaniusz, który przez swe dzieło literackie i udział w sporach dogmatycznych — dodajmy — nie zawsze szczęśliwy, wsławił Kościół cypryjski $^{26}$. W V w. wybuchł spór związany z Cyprem, który sprawił, że sobór efeski w $431 \mathrm{r}$. oraz cesarze $\mathrm{V}$ w. musieli się zająć problemami wyspy ${ }^{27}$.

Cypr administracyjnie wchodził w skład diecezji (cywilnej) wschodu, a jej prefekt rezydował w Antiochii. Stąd też biskupi Antiochii, którą św. Hieronim

${ }^{18}$ Auxibius (BHG 204).

${ }^{19}$ Heraclides (BHG 743); R. Halkin, ABol 82 : 1964 s. $139-169$; M. van Esbrock, ABol 103 : 1985 s. $115-162$.

${ }^{20}$ Por. Iose phus Flavius, Antiquitates $16,4,5$.

$21 \mathrm{Dio}$ Cassius 68,32 .

22 Euzebiusz z Cezarei, Męczennicy palestyńscy 13, 2. 69,75 .

${ }^{23}$ M a si II, 696; H. Gelze r [...], Patrum Nicaenorum nomina [...], Lipsiae 1898, s. 46 -49,

${ }_{24}$ Rufinus, Historia ecclesiastica 1, 5, PL 21 s. 471 n.; por. P. v a n de n V e n, La légende de

S. Spiridion, évêque de Trimithonte, Louvain 1953.

${ }^{25}$ Rufinus, PL 21 s. $471 \mathrm{n}$.

${ }^{26}$ SWP $132-134$.

${ }^{27}$ Hefele-Laclercq 2/1 s. $335-337$; A. Palmieri, DThC $2 / 2$ s. $2428-2431$. 
nazywal metropolią Wschodu ${ }^{28}$, postanowili podporządkować sobie Kościól cypryjski, czego przejawem miało być prawo święcenia przez nich metropolitów wyspy. Swe pretensje opierali głównie na 6 . kanonie soboru nicejskiego (uwzględniając także 4.), który głosił, że jak Aleksandria ma prawa nad Libią i Pentapolem, tak trzeba zachować stare prawa Kościoła w Antiochii; dodawal jednak: zachowując prawa innych eparchii ${ }^{29}$. Również 37 . kanon z tzw. Kanonów arabskich soboru Nicejskiego pozwalał w drodze wyjątku, o ile arcybiskup Cypru umarłby w zimie, gdy utrudniona jest żegługa morska, na wybranie metropolity na Cyprze ${ }^{30}$, aby nie było przerwy władzy. Dodać należy, że kanony te są apokryfem pochodzącym z czasów po soborze efeskim. Tak więc patriarcha antiocheński Aleksander ( $†$ 418) zwrócił się do papieża Innocentego I $(† 417)$ ze skargą na mieszkańców Cypru. Uważał on, że posiada uprawnienia względem Kościoła cypryjskiego. Papież uznał prawa patriarchy nad całą diecezją (w znaczeniu cywilnym) i upomniał cypryjczyków ${ }^{31}$. Ci jednak nie mieli bynajmniej zamiaru podporządkować się tym zarządzeniom, uważając, że Antiochia nigdy nie sprawowała takowej władzy nad Cyprem. Przypomnieli, że kanon nicejski mówił o zachowaniu praw eparchii, a panoszenie się arian w Antiochii w czasie schizmy melecjańskiej było najlepszym argumentem przeciw zależności od niej Cypru.

Do ostatecznej rozgrywki postanowiono wykorzystać zwołany właśnie sobór efeski. Zmarł bowiem metropolita Salaminy Troilos i Jan, Patriarcha antiocheński, chciał sprawę definitywnie załatwić. Na jego prośbę komes Teodor napisał dwa listy: jeden do biskupów cypryjskich, drugi do mieszkańców wyspy, zakazując wyboru metropolity do czasu, aż sprawę załatwi sobór. Ale ani biskupi, ani mieszkańcy nie zareagowali na list komesa i wybrali nowego metropolitę Reginosa, który wraz z trzema sufraganami wybrał się na sobór i sprawa była rozpatrywana na VII sesji, 31 lipca $431 \mathrm{r} .{ }^{32}$ Biskupi cypryjscy trafili na pomyślną dla siebie sytuację. Sobór bowiem był nieprzychylnie ustosunkowany do Jana antiocheńskiego, który popierał Nestoriusza; dodajmy, wraz z innymi sufraganami antiocheńskimi był on nieobecny na sesji. Sobór sformułował jednak swoją deklarację bardzo ostrożnie: uznaje samodzielność Cypru, chyba że Antiochia udowodniłaby swe prawa. Nie jest to więc określenie ostateczne ${ }^{33}$. Pierwszy etap walki został wygrany, choć sprawa nie została przesądzo na definitywnie. Zwróćmy uwagę na fakt, że biskupi cypryjscy w swej argumentacji nie powołują się na apostoła Barnabę ani na jego grób na Cyprze.

W połowie V w. sytuacja odwróciła się. Patriarchą Antiochii był Piotr Folusznik, monofizyta, a cesarzem, sprzyjający monofizytom, Zenon. Piotr po-

${ }_{28}^{28}$ Contra Ioannem Hierosolymitanum, PL 23, 389.

${ }^{29}$ S. Wlod a rs ki, Siedem soborów ekumenicznych, Warszawa 1968, s. 47.

30 Mansi2, 64.

31 PL 20 s. $547-549$.

${ }^{32} \mathrm{Hefele}$-Leclercq 2/1334-337; ACO I 5 s. $357-360$; I 1, 7 s. 118 n.

${ }^{33}$ Kanon 7; P. P. J o a n no u, Les canons des concils ecumeniques, Rome 1962, s. $63-65$. 
stanowił podporządkować sobie Cypr. Sytuacja dla Cypru była krytyczna tym bardziej, że arcybiskup Cypru Antemiusz nie był zbytnio wymowny. Wtedy miał mu się ukazać apostoł Barnaba, który wskazał mu miejsce swojego grobu. W 488 r. odkryto ciało Barnaby: na piersiach miał mieć położony egzemplarz Ewangelii św. Mateusza. Antemiusz zawiózł Zenonowi Ewangelię. Cesarz uznał odkryty grób apostoła jako wystarczający argument dla nadania Cyprowi autokefalii i polecił patriarsze Konstantynopola zwołać synod, który by ją uznał, a metropolicie cypryjskiemu nadał szereg przywilejów. Wiadomości o tym wydarzeniu podają pisarze VI w.: Teodor Lektor, Sewer z Antiochii, Aleksander mnich, Wiktor z Tonnuny oraz, około roku 1000 - Księga Suda ${ }^{34}$.

Cudowne odkrycie ciała apostoła spowodowało powszechne uznanie pochodzenia apostolskiego kościoła cypryjskiego, którego gwarantem był grób apostoła. Z tym właśnie wydarzeniem związane jest powstanie Podróży Barnaby oraz Panegiryku Barnaby mnicha Aleksandra, głównych źródeł legendy cypryjskiej. Jej punktem wyjścia jest wiadomość o podróży Barnaby i Jana Marka na Cypr (Dz 15,39).

Legendę cypryjską św. Barnaby znamy z dwóch utworów: Podróży i męczeństwa św. Barnaby apostota oraz z Panegiryku św. Barnaby pióra Aleksandra, mnicha cypryjskiego. Pierwszy utwór załączamy w tłumaczeniu na zakończenie niniejszego artykułu.

Podróże św. Barnaby znamy w oryginale greckim wydanym w Acta Sanctorum, poprawionym następnie przez $\mathrm{K}$. Tischendorfa i wydanym ostatecznie w wydaniu Lipsius-Bonnet. Mamy również stary przekład łaciński tekstu. Autorem Podróży miał być Jan Marek, kuzyn św. Barnaby, towarzysz apostołów w pierwszej podróży misyjnej; dla podkreślenia swojej obecności używa on pierwszej osoby. Jego odejście od towarzyszy w Pamfilii spowodowało, że św. Paweł nie zgodził się, by im towarzyszył w drugiej. Podróże starają się wyraźnie usprawiedliwić Jana Marka, natomiast Aleksander mnich przedstawia go raczej negatywnie, jako lękliwego i obawiającego się trudów. Inne szczegóły biograficzne Marka znajdujemy w obydwu utworach. Z Podróży dowiadujemy się, że po śmierci Barnaby udał się do Aleksandrii, gdzie został ochrzczony; tamże nadano mu imię Marka. Dodajmy, że autor utworu zapomniał, iż na początku utworu podaje, że został on już uprzednio ochrzczony w Ikonium. Inaczej przedstawia dalsze dzieje Marka Aleksander. Marek, wedle polecenia

34 Według Theodora Lektora (Historia ecclesiastica 2, 2; PG 86 (1 s. 184 BC) „znaleziono na Cyprze zwloki apostoła Barnaby pod drzewem świętojańskim. Miał on na piersi ewangelię Mateusza przepisaną własną ręką Barnaby. Z powodu tych wydarzeń uznali mieszkańcy Cypru autokefalię ich metropolii i fakt niepodlegania Antiochii. Tę ewangelię zlożył Zenon w kaplicy św. Szczepana". Sewer z Antiochii (ok. 517) pisze o tym fakcie w liście do Tomasza, biskupa Germanicei (por. J. S. A s s e m a n i, Bibliotheca Orientalis 2, 81; Księga Suda, s. v. Thyîna; Greckie menea pod datą 11; teksty podaje Li ps i u s 292 - 294). Dodać tu należy wiadomość z Kroniki Wiktora z Tonnuny (488), że ciało „św. Barnaby odnaleziono na podstawie jego objawienia się na Cyprze wraz z ewangelią św. Mateusza napisaną jego ręką" (PL 68 s. 947). 
danego mu przez Barnabę przed śmiercią, udał się do Efezu, do św. Pawła, skąd św. Piotr zabrał go do Rzymu, gdzie Marek, napisał swoją Ewangelię; również Piotr udzielił mu święceń biskupich i wysłał do Egiptu, gdzie po dziewięciu latach pracy apostolskiej zginąl śmiercią męczeńską ${ }^{35}$. W tekście łacińskim znajdujemy wyjaśnienie faktu autorstwa księgi. Łukasz bowiem opisał dzieje Barnaby w Dziejach apostolskich. Ponieważ jednak udał się on w podróż ze św. Pawłem, nie znał dalszych losów Barnaby i dlatego zadania opisania ich podjął się Jan Marek ${ }^{36}$.

Podróże są utworem wyjątkowo niespójnym i chaotycznym, nawet jak na apokryf. Pierwsza ich część służy wyjaśnieniu sporu, który wybuchnął między Pawłem a Barnabą. Wszystkie trzy osoby zainteresowane mają widzenia. Druga część zasadniczo jest poświęcona podróży cypryjskiej, sporo jednak miejsca zajmują wydarzenia poprzedzające przyjazd na Cypr. Wędrówka po Cyprze wykazuje, jak twierdzą znawcy topografii cypryjskiej, dobrą znajomość wyspy. Zygzaki tej podróży można łatwo wytłumaczyć chęcią wykazania obecności apostoła we wszystkich ważniejszych centrach Cypru. Sam utwór robi wrażenie nieporęcznego zlepku różnych elementów, dość chaotycznie złożonych razem, o różnych tendencjach teologicznych; przebadanie ich pozostaje do zrobienia.

Elementem charakterystycznym dla Podróży jest negatywny stosunek do Żydów. Wrogiem numer jeden jest mag Barjesu, znany z Dziejów apostolskich, który przeszkadzał Barnabie w jego pracy apostolskiej. $\mathrm{Z}$ jego poduszczenia Żydzi zabijają i palą Barnabę. Wrogość pogan nie jest tak silnie podkreślona. Czy nie są to przypadkiem reperkusje roli silnej gminy żydowskiej na Cyprze przed rokiem 116 oraz pogromu dokonanego przez Żydów w tym roku na mieszkańcach wyspy?

Drugim utworem podającym legendę cypryjską św. Barnaby jest Panegiryk św. Barnaby, którego autorem jest mnich i kapłan Aleksander, klucznik w klasztorze zbudowanym nad grobem św. Barnaby w Salaminie. Posiadamy również jego tekst grecki wydany przez Papenbroecha w Acta Sanctorum, a jego przekład łaciński znajduje się w Patrologia Graeca.

Układ Panegiryku jest inny niż Podróży. Składa się on z czterech części. Pierwsze dwie mówią o życiu i śmierci Barnaby, dalsze dwie są poświęcone nadaniu Cyprowi autokefalii. Pierwsza część podaje zasadniczo dane zawarte w Dziejach apostolskich, uzupełniając je jednak, jak to już poprzednio widzieliśmy. Druga część (rozdziały 20 do 30) opowiada o jego działalności na Cyprze. Ważną dla nas jest wzmianka w pierwszej części o jego podróży do Rzymu: po przybyciu do Antiochii udaje się na cały świat, odwiedza Rzym i Alek-

${ }^{35}$ Rozdział 30. O Janie Marku por.: A. Niero, Questioni agiografiche di S. Marco, „Studi Veneziani" $12: 1970$ s. $3-27$.

${ }^{36}$ Cytuje Lipsius 278. 
sandrię, a następnie powraca do Antiochii, aby przyprowadzić Pawła z Tarsu. W czasie ich podróży misyjnej opuszcza ich Marek, lękając się podróży i niebezpieczeństw, i powraca do Jerozolimy. Gdy apostołowie powrócili z podróży, witani w Jerozolimie z honorami, Marek, widząc cześć przez nich odbieraną, stara się ich przebłagać, ale udaje mu się to tylko względem Barnaby. Przed drugą podróżą misyjną wybucha spór Pawła i Barnaby o Marka. Autor stara się go wyjaśnić. Podróż misyjna po Cyprze jest opisana bez podawania szczegółów. Barnaba przeszedł Cypr, głosząc Ewangelię. Gdy do Salaminy przybyli Żydzi z Syrii, podburzyli przeciw niemu tamtejszą gminę. Barnaba zgromadził swoich uczniów i wygłosił do nich mowę pożegnalną, w której przepowiada swoją śmierć ${ }^{37}$, i odprawił Eucharystię. Janowi Markowi polecił, aby po jego śmierci zajął się jego ciałem i wskazuje mu, skąd ma je wziąć. Następnie głosił Ewangelię w synagodze, gdzie został pochwycony przez Żydów, którzy zawlekli go do jakiejś synagogi, trzymali do nocy, a potem ukamienowali; chcieli także spalić jego ciało, ale nie zdołali. Jan Marek odnalazł jego ciało i wraz z towarzyszami pochował w jaskimi, 10 stadiów od miasta; na piersi położył egzemplarz ewangelii św. Mateusza. W mieście wybuchło prześladowanie, wierni zostali rozproszeni, a o grobie zapomniano. Na miejscu jednak, w którym się znajdował, miały miejsce liczne uzdrowienia, tak że miejsce to nazwano „miejscem uzdrowień", choć nie umiano ich wyjaśnić.

Autor nie zna lub nie chce podawać detali podróży św. Barnaby po Cyprze. Czytał jednak Klementyny, gdyż podaje wzmiankę o pobycie Barnaby w Rzymie: nie wie natomiast o jego pobycie w Mediolanie. Mówi o pochowaniu ciała, a nie prochów, choć, jak się wydaje, zna wersję o spaleniu ciała, podaną w Podróżach. Stara się je więc pogodzić: próbowano spalić ciało, ale się to nie udało dzięki Bożemu zrządzeniu.

Trzecia część przynosi opis knowań Piotra Folusznika przeciw biskupom cypryjskim oraz objawienie się metropolicie Cypru Antemiuszowi św. Barnaby, który pokazuje mu miejsce, gdzie go pochowano. Ma to być dowodem, że wyspa ma swojego apostoła. Antemiusz znajduje grób Barnaby w miejscu wskazanym pod drzewem janowca, a w nim ciało apostoła z Ewangelią na piersi. Antemiusz udaje się do Konstantynopola, opowiada cesarzowi o odkryciu i ofiarowuje Ewangelię, która zostaje umieszczona w kaplicy cesarskiej. Cesarz nakazuje patriarsze zwołać synod w celu ustanowienia autokefalii Cypru. Antemiusz wraca z Konstantynopola obdarzony licznymi podarkami i przywilejami, buduje nad grobem apostoła kościół i kompleks budynków, ustanawia jego święto na 11 czerwca.

Jak widzieliśmy, uwaga Podróży koncentruje się na wędrówce św. Barnaby po Cyprze, natomiast śmierć potraktowana jest epizodycznie. Inaczej rzecz ma się w Panegiryku, gdzie śmierć i pogrzeb stanowią element najważniejszy.

${ }^{37}$ Mowa ta przypomina mowę pożegnalną św. Pawła w Milecie (Dz 20, 17). 
W obydwu utworach podkreślono rolę księgi Ewangelii Mateusza; w Podróżach apostoł kładze ją na chorych i ci zostają uzdrowieni.

Pozostaje sprawa określenia czasu powstania obydwu utworów. Podczas soboru efeskiego (431) nie było jeszcze mowy o grobie św. Barnaby, a argument ten pojawia się dopiero po cudownym odnalezieniu ciała w $488 \mathrm{r}$. Wydawałoby się więc, że Podróże i Panegiryk powstały po tej dacie. Trudność jednak sprawia opis spalenia ciała, zawarty w Podróżach. Próba pogodzenia spalenia ciała, a zarazem odnalezienia całego ciała, zawarta w Panegiryku, świadczy o powstaniu tego utworu po Podróżach. Ale jak pogodzić opis spalenia ciała - zwłaszcza że podkreślono fakt zmienienia się kości w proch $-\mathrm{z}$ faktem odnalezienia ciała? Wyjaśnienia Lipsiusa są niewystarczające ${ }^{38}$.

Wydaje się, że można sformułować następującą hipotezę. Wobec warunkowości 7. kanonu z Efezu, Cypryjczycy zaczęli szukać silniejszych argumentów dla jego podparcia. Wczytując się w Dzieje apostolskie, rozwijają wzmiankę w nich zawartą o podróży Barnaby i Jana Marka na Cypr. Robią więc z Jana Marka kronikarza tej wyprawy po ważniejszych miastach Cypru, które w VI w. były stolicami biskupimi. Utwór nie jest zupełnie fantazyjny, gdyż włączają do niego tradycje cypryjskie o biskupach, którzy żyli w różnych czasach od II do V w. Stąd też imiona figurujące w Podróżach nie są fikcyjne, ale należą do postaci historycznych, umieszczonych jedynie w czasach Barnaby. Ponieważ jednak nie było na Cyprze grobu Barnaby, opisano jego spalenie. Słabą stroną tej hipotezy jest niemożność wyjaśnienia roli, jaką odgrywa Ewangelia św. Mateusza. Ta legenda powstałaby między rokiem 431 a 488 .

Odnalezienie ciała wprowadza zupełnie nową sytuację. Należy więc pogodzić dane Podróży z nowymi faktami. Tak powstała legenda przekazana przez Panegiryk. Tu datacja jest pewniejsza. Utwór powstał około połowy VI w., ponieważ: primo — podaje nieścisłe wiadomości o cesarzu Zenonie, a więc nie

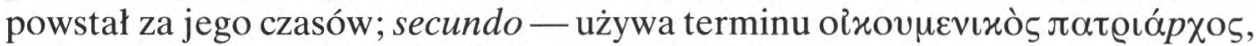
użytego po raz pierwszy w 518 roku na synodzie konstantynopolitańskim; tertio - powstał przed 648 rokiem, kiedy Salamina została złupiona przez Arabów ${ }^{39}$.

Dodajmy jeszcze, tytułem ciekawostki, która, być może, zainteresuje historyków sztuki, opis kształtów zewnętrznych św. Barnaby, zawarty w Panegiryku. Tak miał wyglądać apostoł Cypru: Wszyscy czcili Barnabę, bo łaska była rozlana na jego obliczu. Było ono anielskie, postać natomiast miał ascetyczną. Brwi mu się zbiegły, a oczy radosne nigdy nie spoglądały koso, ale były skromnie spuszczone. Miał godne usta i piękne wargi pozdrawiające słodyczą miodu. Nigdy nie usłyszałeś od niego czegoś, co byłoby zbędne. Chód miał godny

\footnotetext{
${ }_{38}$ Lipsius 303.

39 Tamże.
} 
i pozbawiony chełpliwości. Jednym słowem apostoł Barnaba był jakby czystym pomnikiem Chrystusa, cały jaśniejący cnotą (r. 25).

\section{LEGENDA RZYMSKA}

Wiadomości o pobycie Barnaby w Rzymie znajdujemy w Klementynach. Pisma te powstały w II/III w. i składają się z dwóch części: Recognitiones i Homilie. Recognitiones mamy w łacińskim przekładzie Rufina $\mathrm{z}$ IV w., natomiast Homilie zachowały się w oryginale greckim, stąd też przyjmuje się priorytet danych zawartych w Homiliach nad tymi, które znajdują się w Recognitiones.

Wedle Recognitiones Barnaba głosił naukę Jezusa w Rzymie i tam nawrócił Klemensa. Klemens udał się do Cezarei, gdzie Barnaba wprowadził go do Pio$\operatorname{tra}^{40}$. Nieco inaczej przedstawia się to opowiadanie w Homiliach: w Rzymie naukę Chrystusową głosił pewien człowiek, a gdy Klemens, zachwycony jego nauką, udał się do Palestyny, wiatry zepchnęły go do Aleksandrii, gdzie poznał Barnabę ${ }^{41}$. On go pouczył i razem ruszyli do Cezarei. Ta wiadomość o pobycie w Rzymie znajduje potwierdzenie w apokryficznych Aktach Piotra (z Vercelli) z III w. ${ }^{42}$ Te dwa dokumenty stanowią podstawę dla innych, mówiących o pobycie Barnaby w Rzymie, a więc dla różnych Katalogów apostołów ${ }^{43}$, pochodzących z wczesnego średniowiecza oraz dla Historia Datiana $17 \mathrm{n}$. Wiele z nich łączy pobyt Barnaby w Rzymie z pobytem w Mediolanie. Jak już wspomnieliśmy, mnich Aleksander (połowa VI w.) określa dokładnie ten pobyt rzymski: przed udaniem się po Pawła do Tarsu (tj. pomiędzy Dz 11,22 a Dz 11,25).

Dane te zostały wykorzystane w XIX w. przez Harnacka i Lipsiusa jako dowód przeciw prymatowi papieskiemu. Pobyt Barnaby przed Piotrem w Rzymie odejmuje temu ostatniemu chwałę pierwszego biskupa Rzymu; toteż Kościół rzymski robił wszystko, by zapomniano o tym pobycie Barnaby w Rzymie, w którym nawet nie ma kościoła poświęconego towarzyszowi św. Pawła ${ }^{44}$. Tego rodzaju uwagi dwóch wielkich przecież historyków Kościoła dzisiaj nas mogą tylko śmieszyć, ale są obrazem zaciekłości antyrzymskiego fanatyzmu w pewnych kołach protestanckich. Harnackowi dał odpowiedź Luis Duches-

${ }^{40}$ Recognitiones $1,7-12$.

${ }^{41}$ Homiliae 1, 9-14; $2,4$.

42 Les Actes de Pierre, ed. L. V o a ux, Paris 1922, s. 250.

43 T. Schermann, jw., 118, 4; 117, 16.

44 „Theologische Literaturzeitung” $1876 \mathrm{nr} 19$ s. 478: Tradition von der roemischen Wirksamkeit des Barnabas musste dem roemischen Bischofe unbequem werden: denn sie drohte die einzigartige Bedeutung des Patrus fuer das Abendlande und die einzigartige Stellung Roms im Abendlande zu gefaehrden. Wirklich erreicht es Rom, dass eine Wirksamkeit des Barnabas in Rom vor der des Petrus und in spaeterer Zeit mehr und mehr in Vergessenheit geraeth. Barnabas Roma expellitur. Aber die abendlaendische Wirksamkeit dieses Apostels laesst sich nicht mehr austilgen, und so wandert der roemische Barnabas, wie oftmals ein unbequemer vertriebener Heiliger aus und gelangt nach Mailand. 
ne, kpiąc i ironizując ${ }^{45}$. Trudno bowiem uznać za tradycję sprzeczne zresztą wiadomości zawarte w utworze beletrystycznym oraz oparte na nim pełne fantastycznych wiadomości Katalogi apostołów.

Jeśli jednak chodzi o argument braku zainteresowania Barnabą w Kościele rzymskim, trzeba tu dodać, że w Rzymie do XIV w. istniał kościół pod wezwaniem św. Barnaby — S. Barnaba in Porta, a imię jego firuguje w kanonie rzymskim zawartym w Sakramentarzu gelazjańskim, być może już w VI w., oraz w Martyrologium Bedy i w innych martyrologiach ${ }^{46}$.

Można więc mówić o legendzie rzymskiej apostoła Barnaby, nie można natomiast mówić o tradycji rzymskiej.

\section{LEGENDA MEDIOLAŃSKA}

Z Rzymu miał się udać św. Barnaba do Mediolanu, a ucznia swego wysłać do Brescii. Jako podstawę tej legendy podaje się dwie inskrypcje, ponoć z IV w., będące jednak dziełem humanistów z XVI w. W szeregu, już wspomnianych Katalogów apostołów znajdują się wzmianki o podróży Barnaby do Mediolanu. Katalogi te sięgają, w najlepszym wypadku, wieku VII ${ }^{47}$. Opis pobytu Barnaby w Mediolanie znajduje się w Historia Datiana. Barnaba po oddzieleniu się od Pawła udał się na Cypr, a następnie do Rzymu, w ósmym roku panowania cesarza Klaudiusza (czyli w roku 42) i tam nawrócił Klemensa. Następnie udał się do drugiego miasta Italii, Mediolanu i sanxit ut Mediolanensis, quam ipse fundaverat, principalis ecclesiastici culminis sedes aliarumque in ea provincia ecclesiarum metropolis perpetualiter habeatur. Wydawca tego tekstu tak słusznie komentuje te słowa: l'affermarsi della autorità metropolitica della Chiesa Milanese su le altre della regione è qui giustificata e corroborata dalla fondazione apostolica di essa (s. 20).

Mimo dyskusji i wahań dotyczących datacji tego dokumentu, należy go uznać za dzieło pochodzące z XI w., okresu walk Mediolanu, Rawenny i Akwilei o supremację kościelną nad północną Italią. Po raz drugi legenda związana z postacią Barnaby służy do wywalczenia sobie niezależności przez Kościól lokalny. Stąd też nie bez słuszności stwierdza L. Duchesne: Saint Barnabe avait tiré d'embarras ses fidèles de Chypre, ou plutôt leur métropolitain, et assuré à celui-ci une complète indépendence à l'égard du patriarchat d'Antioche. Ce n'est pas le seul service qu'il ait rendu en ce genre d'affaires. En Occident aussi

45 Quant à présenter de tels récits comme des „traditions" c'est comble le de l'hypercritique. Nul ne'est encore avisé de considérer l'épisode de Quasimodo comme une tradition conservée par les chanoines de Notre-Damme [...] Hommes pieux, séchez vos larmes! Outre ques Barnabé n'a pu être chassé de Rome, par la bonne raison, qu'il n'y est jamais entré, on peut montrer que les Romains on été meilleurs pour lui que vous ne pensez (L. Duchesne, s. 6 n.; por. 34).

${ }^{46}$ L. Duchesne, jw., s. $7-9 ;$ EK 2, 37.

${ }^{47}$ T. Schermann, jw., 118, 14; 184, $4 ; 179,2$. 
on c'est réclamé de lui pour soutenir une métropole attaquée dans ses privilèges $^{48}$.

Jeśli świadectwa legendy mediolańskiej są bardzo słabe, to istnieją świadectwa, które jej przeczą. I tak nie wspominają o Barnabie starochrześcijańscy pisarze pochodzący z Italii północnej, jak Gaudencjusz z Brescii czy św. Ambroży. Ten ostatni, mówiąc w De Spiritu Sancto (2.155 - 157) o św. Barnabie nie wspomina o jego misji w Mediolanie ${ }^{49}$. Podobnie w Contra Auxentium (18) wylicza swoich sławnych poprzedników Dionizego, Eustorgiusza, Miroklesa, nie wymienia Barnaby ${ }^{50}$. Także papież Innocenty I (†417) podkreśla, że na Zachodzie nie ma kościołów, które nie byłyby założone przez św. Piotra.

Reasumując to, co zostało powiedziane o Barnabie, możemy stwierdzić, że wiadomościami historycznymi, dotyczącymi Barnaby, są tylko te, które znajdujemy w Dziejach apostolskich. Prawdopodobny jest również fakt, że nauczał i umarł na Cyprze. Wszystkie inne wiadomości możemy uznać za legendarne, choć niektóre dane, jak widzieliśmy, zawarte w Panegiryku mają pewną dozę prawdopodobieństwa. Legenda cypryjska powstała w ogniu walki o autokefalię Cypru, mediolańska — w walce Mediolanu o supremację w Italii północnej; stoimy tu więc wobec ciekawego przykładu wykorzystania apokryfów. Trudno jest natomiast ustalić źródło i powody powstania legendy rzymskiej. Podróże św. Barnaby, Panegiryk, Akta św. Heraklidesa oraz św. Auksibiusza stanowią bardzo ważne dokumenty do historii Cypru, choć niewiele mówią o czasach św. Barnaby.

\section{SAN BARNABA NELLA STORIA E NELLA LEGGENDA}

\section{Riassunto}

Dalla bibliografia aggiunta a quest'articolo risulta che la persona di S. Barnaba non ha suscitato nella storiografia moderna un grande interesse. Anche, presso gli scrittori antichi troviamo poche notizie sull'apostolo di Cipro: sparse informazioni qua e là nonchè due opere intiere a lui dedicate: Viaggi e martirio di S. Barnaba - opera attribuita a Marco, discepolo di Barnaba, e il Panegirico di Barnaba di Alessandro di Cipro.

Nell'articolo presente trattiamo anzituto della vita di S. Barnaba, prima del suo secondo viaggio a Cipro, fondandoci principalmente sui dati biblicii (Atti degli Apostoli) e completandoli eventualmente con notizie prese da altre fonti. Con la notizia del secondo viaggio a Cipro $($ Atti 15,31$)$ terminano le informazioni sicure su S. Barnaba.

\footnotetext{
${ }^{48}$ L. Duchesne, jw., s. 13.

49 PL 16 s. 776.

50 PL 16 s. 1012.
} 
Per poter studiare la leggenda cipriota di S. Barnaba bisogna delineare la storia della Chiesa a Cipro. Sul cristianesimo ciprio nel s. II e III non si sa niente di sicuro: le vite dei vescovi di quel periodo sono leggendarie. Con il s. IV la Chiesa cipriota esce dall'ombra. Per la formazione della nostra leggenda particolarmente importante è il secolo $\mathrm{V}$. periodo della lotta dei vescovi dell'isola con Antiochia per ottenere l'autocefalia della Chiesa cipriota. Nel Concilio di Efeso essi ricevono un ipotetico riconoscimento, mentre alla fine del secolo l'ottengono definitivamente dopo la scoperta del corpo dell' Apostolo.

Sul soggiorno cipriota di Barnaba parlano ambedue le opere soprecitate. I Viaggi, attribuiti a Marco, compagno di Barnaba, sono divisi in due parti: la prima racconta fatti più o meno parallelli ai dati biblici, mentre la seconda parla, abbastanza caoticamente, del viaggio di Barnaba per varie città di Cipro, finito con il suo martirio; il suo corpo viene bruciato. Nel Panegirico soltanto la seconda parte è dedicata ad una sommaria descrizione del viaggio e del martirio: il suo corpo viene sepolto. Le parti seguenti descrivono la lotta per l'autocefalia della Chiesa cipriota. Quanto alla datazione delle due opere, ci sembra, che i Viaggi siano stati scritti dopo il Concilio di Efeso (431) ma prima della scoperta del corpo (488), il Panegirico invece, non molto dopo il ritrovamento del corpo. Per quanto riguarda la leggenda romana, essa si basa sui dati incerti delle Peudo-Clementine (Recognitiones) e degli apoocrifi Atti di Pietro (Vercellesi). La leggenda milanese ha un fondamento ancora più debole: i dati dei Cataloghi degli Apostoli e della Historia Datiana del secolo XI. Ci sembra difficile ritrovare lo scopo di composizione della leggenda romana, mentre quella milanese è sorta dalla lotta per la supremazia ecclesiastica nell'Italia Settentrionale. La seconda parte dell'articolo dà una traduzione polacca dei Viaggi ed una bibliografia su S. Barnaba.

\section{ANEKSY}

I

\section{WĘDRÓWKI I MĘCZEŃSTWO SW. BARNABY}

1. Po odejściu Zbawiciela naszego Jezusa Chrystusa, niestrudzonego, miłującego ludzi, potężnego pasterza, nauczyciela i lekarza, oglądałem własnymi oczami niewypowiedzianą, świętą i niepokalaną tajemnicę chrześcijan, święcie posiadających nar łem.

2. Ja Jan* uważałem za konieczne opowiedzieć tajemnicę, którą słyszałem i starałem się opowiedzieć. Towarzyszyłem bowiem świętym apostołom Barnabie i Pawłowi ja, który niegdyś byłem sługą Cyryla, kapłana Zeusa*. Teraz

2. Jan - Zmiana imienia na Marek, zapowiedziana tu, zostaje dokonana w rozdziałach 3 i 6 . Obydwa imiona występują równolegle w Piśmie św. Por. Ni e ro, art. cyt. $3-6$.

Zeusa - Niemożliwą jest rzeczą, by Żyd mógl być sługą kapłana pogańskiego, tym bardziej jego 
jednak otrzymałem łaskę Ducha Świętego przez Pawła, Barnabę i Sylasa*, godnych swego powołania. Oni mnie ochrzcili w Ikonium.

3. Po chrzcie ujrzałem w widzeniu jakiegoś męża stojącego przy mnie i odzianego w białą szatę. Rzekł on do mnie: „Odwagi, Janie, twoje imię zostanie zmienione na Marek, a sława twoja będzie głoszona na całym świecie. Ciemności, które są w tobie, odejdą od ciebie, a zostanie ci dany rozum dla poznania tajemnic Boga".

4. Ujrzawszy to widzenie przeląkłem się, padłem do stóp Barnaby i powiedziałem mu tajemnice, które ujrzałem i usłyszałem od owego męża. Nie było tam Pawła apostoła, gdy wyłożyłem te tajemnice. Rzekł do mnie Barnaba: „Nie opowiadaj nikomu cudów, które widziałeś i przy mnie tej nocy stanął Pan i powiedział: Odwagi! Jak ty wydałeś swoją duszę dla imienia mego, gotowy zginąć lub oddalić się od swego ludu, tak uczynię cię doskonałym. Prócz tego, weź sługę, który jest $\mathrm{z}$ wami, on bowiem zna pewne tajemnice. Teraz więc, dziecko, strzeż w sobie słów, które widziałeś i słyszałeś. Zbliża się bowiem czas, w którym masz się objawić".

5. Gdy otrzymałem od niego to pouczenie, pozostałem w Ikonium jeszcze 'dość długo. Był tam bowiem mąż święty i bogobojny, który nas przyjął; dom jego bowiem Paweł uświęcił*. Stamtąd udaliśmy się do Seleucji i pozostawszy w nim trzy dni popłynęliśmy na Cypr*. Wyruszywszy z Cypru przybyliśmy do Perge w Pamfilii*. Tam pozostałem około dwóch miesięcy, chcąc udać się na Zachód, ale nie pozwolił mi na to Duch Święty*. Powróciwszy więc szukałem apostołów, a dowiedziawszy się, że przebywają w Antiochii, udałem się do nich.

6. Znalazłem Pawła w Antiochii w łóżku, zmęczonego podróżą. Gdy mnie zobaczył, bardzo użalał się na to, że zatrzymałem się w Pamfilii. Przyszedł Barnaba i pocieszał go; on skosztował chleba, ale wziął go niewiele. Następnie głosili słowo Pańskie i oświecili wielu Żydów i Hellenów. Ja zaś trzymałem się blisko nich, bałem się jednak zbliżyć do Pawła, gdyż zatrzymałem się dość długo w Pamfilii i on się na mnie bardzo gniewał. Padałem przed nim na kolana na ziemię na znak pokuty, ale on nie chciał mnie widzieć. Gdy tak pozostawałem przez trzy tygodnie, błagając go i prosząc na kolanach, nie mogłem jednak zwalczyć jego podejrzliwości względem mnie. Miał do mnie wielki żal, bo zostawiłem większość pergaminów* w Pamfilii.

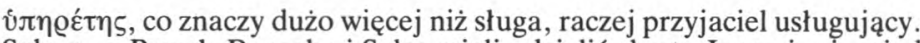

Sylasa - Paweł, Barnaba i Sylas mieli udzielić chrztu Janowi, nie wiadomo jednak, by Sylas byl towarzyszem pierwszej podróży św. Pawła. Wedle rozdziału 26. Jan otrzymał chrzest w Aleksandrii. Pobyt w Ikonium, wedle rozdziału 5., miał miejsce przed pierwszą podróżą św. Pawła. Gdy Barnaba i Paweł przybyli do Ikonium, nie było pośród nich Jana.

5. Uświęcił - Onezyfor z Dziejów Pawta i Tekli 5.

Pamfilii - Por. Dz 16,7.

Święty - podobnie jak Dz 16,7.o odłączeniu się Jana Marka por Dz 13,13, ale miał on udać się do Jerozolimy. Inną wersję podaje Panegiryk (por. wyżej. rozdz. 3b).

6. Pergaminów-por. 2 Tm 4,15. 
7. Pewnej niedzieli, gdy przestali nauczać w Antiochii, wspólnie postanowili udać się do krajów położonych na wschód, a potem pojechać na Cypr, aby odwiedzić wszystkie Kościoły, w których głosili Słowo Boże. Barnaba poprosił Pawła, aby poszedł najpierw na Cypr, aby mógł odwiedzić znajomych w swojej wsi, natomiast Lucjusz* chciał odwiedzić swoje miasto, Koryne (Cyrene). Paweł natomiast otrzymał widzenie we śnie, aby pospieszył do Jerozolimy, bo tam oczekują go bracia. Barnaba jednak prosił, aby udali się na Cypr i tam spędzili zimę, a potem udali się na święto do Jerozolimy*.

8. Powstał więc między nimi wielki spór. Barnaba prosił, abym i ja im towarzyszył, bo byłem ich sługą od początku i służyłem z całkowitym oddaniem na Cyprze aż do przybycia do Perge w Pamfilii, gdzie zatrzymałem się wiele dni. Ale Paweł zawołał do Barnaby, mówiąc: „Niemożliwe, aby on szedł z nami”. $\mathrm{Ci}$, co byli tam z nami, również prosili go, abym i ja mógł towarzyszyć, jako że moim pragnieniem było być z nimi do końca. W końcu rzekł Paweł do Barnaby: „Skoro więc chcesz wziąć z sobą Jana zwanego Markiem, idź inną drogą; nie pójdzie bowiem z nami”. Barnaba zaś zastanowiwszy się rzekł: „Tego, który raz podjął się służby Ewangelii i który wyruszył z nami, nie opuści łaska Chrystusa. Jeśli więc uważasz to za słuszne, ojcze Pawle, wyruszę wziąwszy go ze sobą”. On zaś rzekł: „Idź z łaską Chrystusa, my zaś w mocy Ducha”.

9. Upadłszy na kolana modlili się do Boga. Westchnąwszy Paweł wybuchnął płaczem, podobnie i Barnaba. I mówili do siebie: „Byłoby rzeczą dobrą, gdybyśmy wspólnie skończyli nasze życie między ludźmi, tak jak je zaczęliśmy. Jeśli jednak tobie tak się wydaje, ojcze Pawle, módl się za mną, aby mój trud był doskonały i wyszedł na chwałę [Boga]. Wiesz dobrze, jak tobie służyłem tu wedle łaski, którą dał nam Chrystus. Udaję się na Cypr i spieszę, aby dokonać życia. Wiem dobrze, że nigdy nie ujrzę już twojego oblicza, ojcze Pawle!” I padłszy na ziemię, do jego stóp, głośno zapłakał.

10. Paweł rzekł do niego: „Pan objawił się także i mnie tej nocy i powiedział: Nie przesszkadzaj Barnabie w tym, udać się na Cypr; tam bowiem już mu przygotowano oświecenie wielu. I ty także, dzięki łasce tobie danej, udaj się do Jerozolimy, aby oddać cześć w świętym miejscu. Tam też tobie zostanie wskazane, jaki sposób męczeństwa będzie ci zgotowany". Pozdrowili się nawzajem; mnie zaś wziął z sobą Barnaba.

11. Udaliśmy się do Laodycei i pytaliśmy się, jak można przeprawić się na Cypr. I wyruszyliśmy znalazłszy statek odpływający na Cypr. Gdy zaś wypłynęliśmy, spotkał nas wiatr przeciwny. Przybyliśmy więc do Korasion*, zeszliśmy na brzeg, na którym było źródło i pokrzepiliśmy się tam. Nikomu jednak

7. Lucjusz - por. Rz 16,21; Dz 13,1. Był on rodem z Cyreny, stąd Tischendorf poprawia Kv@ท́vๆv. Jerozolimy — Niezgodność z Dziejami; chodziło o osobę Marka, a nie o kierunek podróży.

11. Korasion - prawdopodobnie chodzi o Korakesion, dziś Aleja, miasto w Pamfilii.

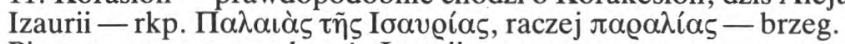

Pityusa - wyspa u wybrzeży Izaurii. 
nie powiedzieliśmy, kim jesteśmy, aby nie wiedziano jeszcze, że Barnaba oddzielił się od Pawła. Opuściliśmy Korasion i przypłynęliśmy do brzegów Izaurii*, a stamtąd udaliśmy się na wyspę o nazwie Pityusa*, a ponieważ złapała nas burza, przebywaliśmy tam trzy dni. Przyjął nas tam mąż pobożny imieniem Eufemos. Barnaba dobrze pouczył jego i cały dom o wierze.

12. Stamtąd płynęliśmy na [wyspy] Akonesia i przybyliśmy do miasta Anemurios* i gdy tam weszliśmy, znaleźliśmy dwóch Greków. Przyszli do nas i zapytali, skąd przychodzimy i kim jesteśmy. Rzekł do nich Barnaba: „Jeśli chcecie wiedzieć, skąd przychodzimy i kim jesteśmy, zrzućcie szaty, które nosicie, a ja was odzieję w szatę, która nigdy się nie brudzi: nie ma na niej skazy, ale zawsze pozostaje świetlana”. Oni zaś zdziwili się na te słowa i pytali nas: „Jaka to jest ta szata, którą chcesz nam dać?” Rzekł do nich Barnaba: Jeśli wyznacie wasze grzechy i przylgniecie do Pana naszego, Jezusa Chrystusa, odziejecie się w owe szaty, które pozostają nieskalane na wieki”.

13. Przejęci żalem za sprawą Ducha Swiętego, padli do jego stóp i prosząc mówili: „Błagamy cię ojcze, daj nam tę szatę. My bowiem wierzymy w Boga żywego i prawdziwego, którego głosisz". Zeszli więc do źródła i ochrzcił ich w imię Ojca i Syna i Ducha świętego. A oni poznali, że zostali odziani w moc i w świętą szatę. Wziąwszy ode mnie jedną szatę odział jednego, a swoją szatą odział drugiego. Przynieśli mu pieniądze, które Barnaba natychmiast rozdał ubogim.

14. Skorzystali z nich obficie także marynarze. Gdy zeszliśmy na brzeg, głosił im słowo Boże. I pobłogosławiwszy pożegnaliśmy ich i weszliśmy na statek. Jeden z nich, imieniem Stefan, chciał nam towarzyszyć, ale Barnaba mu nie pozwolił. Wypłynęliśmy i dopłynęliśmy nocą do Cypru, i weszliśmy do [miasta] Krommyakite*, i znaleźliśmy tam Tymona i Arystona, sługi Boże*, u których przenocowaliśmy.

15. Tymon miał wysoką gorączkę. Włożyliśmy na niego ręce i natychmiast ustąpiła mu gorączka na wezwanie imienia Pana Jezusa. Otrzymał bowiem Barnaba [księgę] nauk Mateusza, w której spisano Boże słowa, cudy i nauki. Tę to księgę Barnaba kładł na chorych, gdy przechodziliśmy przez ową krainę, i natychmiast uzdrawiał ich $\mathrm{z}$ chorób.

16. Gdy przybyliśmy do Lapithos*, w teatrze odbywało się przedstawienie bałwochwalcze i nie pozwolono nam wejść do miasta, lecz odpoczęliśmy nieco przy bramie. Tymon po uzdrowieniu szedł z nami. Wyszedłszy z Lapithos szliśmy przez góry i doszliśmy do miasta Lampadistos, skąd pochodził Tymon.

12. Anemurium - przylądek w Cylicji, skąd najbliżej na Cypr. Na nim miasto Anamur.

14. Krommyakite - Kromnion, Ceparum, dziś Kormachitis, przylądek na Cyprze najbardziej wysunięty w kierunku Azji Mniejszej.

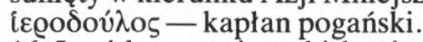

16. Lapithos - miasto biskupie na płn. wybrzeżu Cypru.

Herakleona - mimo posiadania jego życiorysu nie jesteśmy w stanie powiedzieć o nim czegokolwiek. Mial być biskupem w Tamasos. Delehaye przypuszcza, że był on biskupem przed wiekiem $\mathrm{V}$, po którym pozostała blogosławiona pamięć. Jego grób znajduje się w Hagios Heraklis. Por art. Delehaye, 337 - 339 . 
U niego też znaleźliśmy Herakleona*, który tam przebywał, i zamieszkaliśmy u niego.

17. Pochodził on z Tamasos*, skąd przyszedł w odwiedziny do swojej rodziny. Skoro Barnaba spojrzał na niego uważnie, poznał go, bo spotkał był go już uprzednio, gdy był z Pawłem w okolicach Kition*. Udzielił mu więc Ducha św. na chrzcie i zmienił mu imię na Heraklidesa. Włożył na niego ręce i uczynił go biskupem Cypru. Umocniwszy [w wierze] Kościół w Tamasos, pozostawiliśmy go, aby kierował braćmi, którzy tam mieszkali.

18. My zaś przeszliśmy góry zwane Chiomodes* i doszliśmy do Starej Pafos*, a tam znaleźliśmy Rodona, pewnego sługę Bożego; on uwierzywszy towarzyszył nam. Spotkaliśmy też pewnego Żyda imieniem Barjesu, pochodzącego z Pafos, który poznał, że Barnaba był poprzednio z Pawłem. On to właśnie nie pozwolił nam wejść do Pafos. Wobec tego zawróciliśmy i poszliśmy do Kurion*.

19. I zobaczyliśmy, że mają tam miejsce zawody nieczyste na drodze blisko miasta: biegł tłum nagich kobiet i mężczyzn; wielki był bowiem błąd i uwiedzenie w owym miejscu. Odwróciwszy się więc Barnaba przeklął ich i zawaliła się zachodnia część, tak że niemało zostało zranionych; wielu spośród nich umarło, a pozostali uciekli do pobliskiej świątyni Apollina, zwanej Hiera*. Gdy zbliżyliśmy się do Kurion, stanął na drodze wielki tłum Żydów, którzy tam mieszkali, podjudzany przez Barjesu. Stał on przed miastem i nie pozwolił nam wejść do niego. Spędziliśmy więc dzień pod drzewem i pokrzepiliśmy się tam.

20. Następnego dnia weszliśmy do pewnej wsi, w której przebywał Aristoklianos. Został on oczyszczony z trądu w Antiochii. Paweł i Barnaba opieczętowali go biskupstwem i wysłali do rodzinnej wioski na Cypr, bo przebywało tam wielu Greków. Wraz z nim zamieszkaliśmy w jaskini górskiej i tam przebywaliśmy jeden dzień. Stamtąd udaliśmy się do Amathusa*, gdzie w świątyni położonej w górach przebywał wielki tłum bezwstydnych kobiet i mężczyzn, którzy urządzali libacje*. I tam poprzedził nas Barjesu, i przygotował tłum Żydów, i nie pozwolili nam wejść do tego miasta. Jednak pewna wdowa prawie osiemdziesięcioletnia, mieszkająca poza miastem, która również nie oddawała czci bogom, podszedłszy przyjęła nas do swego domu na godzinę. Gdy wychodziliśmy [z miasta], strzepnęliśmy proch z nóg* wobec tej świątyni, w której kapłani składali libacje.

17. Tamasos - ważne miasto na środkowym Cyprze, centrum kultu i przemysłu miedziowego, najstarsze biskupstwo.

Kition - ważne miasto na płd. Cypru, dziś Larnaka. Centrum kultu Afrodyty. Jedno z najstarszych biskupstw.

18. Chiomodes - góry śnieżne, prawdopodobnie Olimp na Cyprze.

Pafos - tam św. Paweł spotkał się z prokonsulem Sergiuszem Pawłem i Barjesu (Dz 13,6 - 13).

Kurion - miasto na płd. zachodzie wyspy, stolica biskupia, dziś Episkopi (Piskopi).

19. Hiera - świątynia Afrodyty, w której, jak podaje Lipsius (s. 288), odkryto ślady.

20. Amathusa - dziś Limisso.

Libacje - związane z kultem Afrodyty.

Nóg - por. Mt 10,14 (par.); Dz 5,51. 
21. Wyszliśmy stamtąd i udaliśmy się przez miejsca pustynne, a szedł z nami Tymon. Gdy przyszliśmy do Kition*, usłyszeliśmy wielki hałas w hipodromie. Gdy dowiedzieliśmy się [jego przyczyny], wyszliśmy z miasta, wszyscy otrząsając pył z naszych stóp; nikt nas tam bowiem nie przyjął. Odpoczęliśmy około godziny koło akweduktu.

22. Z Kition wyruszyliśmy statkiem. Przybyliśmy do Salaminy* i przeszliśmy do tak zwanych Wysp, gdzie znajdowało się miejsce pełne bałwanów; i tam także miały miejsce uroczystości i libacje. Znaleźliśmy tam znowu Heraklidesa i pouczyliśmy go, jak głosić Bożą Ewangelię, jak zakładać Kościoły i jak sprawować w nich kult. Gdy zaś weszliśmy do Salaminy, natrafiliśmy na synagogę blisko tak zwanych Biblii. Tam weszliśmy, a Barnaba otworzywszy Ewangelię, którą był otrzymał od Mateusza, swego współtowarzysza, zaczął nauczać Żydów.

23. Po dwóch dniach, gdy pouczyliśmy niemało Żydów, przybył Barjesu. Rozgniewawszy się, wezwal wielki tłum Żydów, który porwał Barnabę i starał się go oddać prokonsulowi zarządzającemu wyspą. Związali go więc, aby go zaprowadzić do niego. Gdy jednak dowiedzieli się, że przybył Euzebiusz Jebuzyta*, krewny Nerona, Żydzi w nocy schwycili Barnabę, zawiązali mu sznur na szyi i zawlekli go z synagogi do hipodromu. Weszli za bramę i stanąwszy wokół niego spalili go, a kości jego zamieniły się w proch. Natychmiast, tej samej nocy, zebrali popiół do prześcieradła i obciążywszy je ołowiem zamierzali je wrzucić do morza.

24. Ja zaś znalazłem w nocy czas sposobny, i z Tymonem, i Rodonem zdołaliśmy unieść je. I przynieśliśmy je do pewnego miejsca, i znalazłszy jaskinię wnieśliśmy je tam, gdzie niegdyś mieszkali Jebuzyci. Znaleźliśmy tam miejsce ukryte; złożyliśmy je wraz z naukami, które otrzymał od Mateusza. Było to o godzinie czwartej, w drugą noc po szabacie [w poniedziałek].

25. Podczas gdy ukrywaliśmy się w tym miejscu, Żydzi urządzili wielkie poszukiwanie za nami i z trudem znalazłszy nas wypędzili aż do miasta Ledra* . Znaleźliśmy tam jaskinię blisko wsi i uciekliśmy do niej, i tak ukryliśmy się przed nimi. Ukrywaliśmy się w niej trzy dni. A gdy Żydzi odeszli, opuściliśmy te miejsca nocą. I wziąwszy z sobą Aristona i Rodona przybyliśmy do Limnes.

26. Gdy przybyliśmy na brzeg, znaleźliśmy statek egipski i wstąpiwszy nań udaliśmy się do Aleksandrii. Pozostałem tam głosząc zgromadzonym braciom słowo Pana, oświecając ich i głosząc im Ewangelię, której nauczyłem się od apostołów. A oni mnie ochrzcili w imię Ojca i Syna i Ducha Swiętego i zmienili imię na Marek dzięki wodzie chrztu, przez którą mam nadzieję przywieść li-

21. Kition - por. rozdz. 17.

22. Salamina - dziś Famagusta; otaczają ją wyspy.

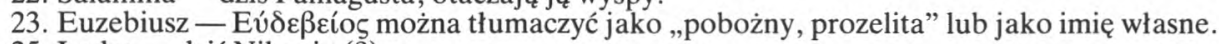

25. Ledra — dziś Nikozja (?). 
cznych do chwały Boga dzięki Jego łasce. Bo Jemu należy się cześć i chwała na wieki wieków. Amen.

\section{BIBLIOGRAFIA PIŚMIENNICTWA DOTYCZĄCEGO ŚW. BARNABY APOSTOŁA}

1. Wydania tekstów źródłowych:

ASanc Iunii 2, 11 Iunii, s. $421-469(415-454)+$ Appendix 35; por. S t e g mueller, RB 1 s. 205.

Teksty greckie (BHG 225 - 226e, 2057):

Podróże: ASanc, jw., s. 431-435 (425-429); K. Tis ch e nd o rf, Acta apostolorum apocrypha, L 1851, s. $64-74$ (por. XXVI - XXXI) R. A. Li psi us, M. B onnet, Acta apostolorum apocrypha, II 2, L 1903, s. 292 302 (por. XXVII) - reprint: Hildesheim 1972.

Panegiryk Aleksandra Cypryjskiego: ASanc, jw., s. 436-452 (431-447); P. v a n D u m, Editie van het Encomium Sancti Barnabae van Alexander Cyprius (maszynopis pracy licencjackiej na Uniwersytecie Katolickim w Leuven; s. 431 - wydanie krytyczne tekstu).

Podróże i męczeństwo Barttomieja i Barnaby: B. Lat y s ze w, Menologii anonymi byzantini [...] quae supersunt, 2, Petropoli 1912, s. $34-40$; por. F. Halkin, Les actes apocryphes de S. Heraclide de Chypre, disciple de l'apôtre Barnabé, ABol 82 : 1964 s. 133 - 170 = Etudes d'epigraphie grecque et d'agiographie, Lo 1973, XII.

Teksty łacińskie (BHL 983 - 990):

A. C. Colom bo, De vita civitatis Mediolani, de adventu Barnabae apostoli [...], Bologna 1951, s. 14 - 21 .

Teksty wschodnie:

M. van E s b r o c k, Les actes arméniennes de S. Heraclide de Chypre, ABol 103 : 1985 s. 115 - 162 (tekst ormiański); BHO s. 201 (Barnaba i Paweł tekst koptyjski).

Teksty słowiańskie:

A. de Santos Otero, Die handschriftliche Überlieferung der slavischen Apokryphen, 1, B 1975, s. 137 n. 
2. Przekłady:

Podróże: J. P. Mign e, Dictionnaire des apocryphes, 2, Paris?, s. $143-148$ (francuski); M. Erbetta, Gli apocrifi del Nuovo Testamento, 2, Casale 1966, s. 597 - 600 (włoski); ASanc, jw., s. 245 - 249 (laciński).

Panegiryk: ASanc, jw., s. 431 - 447; PG 87/3 s. 4087 - 4116 (laciński).

\section{Opracowania:}

G. B a rdy, [w:] DHGE 6 s. $847-849$.

G. B a rdy, [w:] Catholicisme $1 \mathrm{s.} 1255 \mathrm{n}$.

O. Bardenhewer 1 s. 116.

O. Bra unsberger, Der Apostel Barnabas. Sein Leben und ihm beigelegter Brief, Mainz 1876; por. A. von Harn ack, [w:] ThLZ 1 : $1876 \mathrm{nr} 10$.

S. B rock, Barnabas hyios Parakleseos, JTS 15/1 : 1974 s. 93 - 98 (D 4,36).

H. B ru n s, Ein Junger Jesu, B 1937.

D. B u r ge r, L'énigme de Barnabé, „Museum Helveticum” 3 : 1946 s. 180 193.

F. Cabrol, [w:] DACL 1/1 s. $496-498$.

E. Le Camus, [w:] DB 1 s. $1461-1466$.

V. Cavalla, [w:] ECat 2 s. 864 n.

E. D ąbrowski, [w:] PEB 1 s. $147 \mathrm{n}$.

E. Dą browski, Pawet z Tarsu, Warszawa 1953, passim (zwł. s. 95-177)

A. De is s man n, Barnabas, ZNW $7: 1906$ s. 91 n.

A. De is s m a n n, Saints de Chypre II, ABol $26: 1907$ s. $235-242$.

$\mathrm{P}$. va n D e u m, Une vie anonyme de S. Barnabé (BHG 226e), ABol (w dru$\mathrm{ku})$.

S. Dox, L'ordination de Barnabé et de Saul d'après Actes 13,1-3 NRTh 108 : 1976 s. $238-250$.

L. Du chesne, Saint Barnabé, [w:] Mélanges G. B. de Rossi, P - R 1892, s. $41-71=$ Mélanges d'archéologie et d'histoire, suppl. 12.

M. Erbetta, jw., s. 594-600.

F. Fils on, Pioneers of the Primitive Church, NY 1940, s. 83-113.

G. D. Gordini, [w:] BS 2 s. $798-809$.

F. Halk in, Actes de Barnabé et vie de S. Héraclide, ABol 82 : 1964 s. 408.

M. K o u m a, He mone apostolou Barnaba, „Apostolos Barnabas” 23 : $1962 \mathrm{nr}$ $5 / 6$ s. $149 \mathrm{n}$.

A. Kappeler, S. Barnaba in vita s. Pauli, VD 22 : 1942 s. $129-135$.

R. A. Lipsius, Die apokryphen Apostelgeschichten und Apostellegenden, II/2, Braunschweig 1884, s. 270 - 320; reprint: Amsterdam 1976. 
J. T. Madenlides, N. Giannokopulos, A. Mytilenaios, Barnabas, Titos, Timotheos, Larissa 1973, s. 9-37.

A. Metziger, [w:] ECat 2 s. 864.

E. Morini, Apostolicità ed autocefalia in una Chiesa orientale; la leggenda di s. Barnaba e l'autonomia dell'arciverscovato di Cipro nei fonti dei secoli V e VI, „Studi e Ricerche sull' Oriente Cristiano” 2 : 1979 s. 23 - 45.

L. Morald i, Apocrifi del Nouvo Testamento, 2, Torino 1971, s. 1620-1622.

F. N a u, La légende des saints évêques Héraclide, Mnason et Rhodon ou l'apostolicité de l'Eglise de Chypre. Une lettre apocryphe de Paul et Barnabé aux Cypriotes, ROC 12:1907 s. 125 - 138.

Oikonomides, Ho themeliotes tes Ekklesias Kyprou apostols Barnabas, „Apostolos Barnabas” 1931 s. 490-498.

P e r i s t i a e s, Ho thaumaturgos tafos tou apostolou Barnaba, „Apostolos Barnabas" 1931 s. $501-509$.

F. X. Poelzl, Die Mitarbeiter des Weltapostels Paulus, Regensburg 1911, s. $8-46$.

P. Pu ccin elli, Vita di s. Barnaba apostolo, Milano 1649.

P. Puccin elli, Zodiaco della Chiesa Milanese, Milano 1650.

D. T. Rice, The Icon of Cyprus, Lo 1937.

K. Romaniuk, W. Danielski, H. Wagner, [w:] EK 2 s. 36-38.

J. A. S axius, Vindiciae de adventu Mediolanum s. Barnabae apostoli contra nonnullos recentiores aetatis scriptores, Mediolani 1748.

G. A. S o ti ri o u, Ho naos kai ho tafos tou apostolou Barnaba para ten Salamina tou Kyprou, „Kyprikai Spoudai” 1 : 1937 s. 175 - 187.

J. Schmidt, [w:] RAC 1 s. $1207-1217$.

J. P. Tsinopuolos, Hagioi tou Kyprou: 11. Ho apostolos Barnabas, „Apostolos Barnabas" 3 ser. 25 : 1964 s. $143-152$.

4. Ikonografia:

Mrs. J a me s o n, Sacred and Legendary Art, 1, Lo 1888, s. 278 n.

M. Le chner, [w:] LCIK 5 s. 316-320 (bibliografia).

S. Orienti, [w:] BS 2 s. $809-816$.

H. Wegner, [w:] EK 2. s. 37 n. 